\author{
JURNAL PERENCANAAN WILAYAH \\ e-ISSN: $2502-\mathbf{4 2 0 5}$ \\ Vol.6., No.2, Oktober 2021 \\ http://ojs.uho.ac.id/index.php/ppw
}

\title{
Penentuan Daerah Imbuhan Dan Evaluasi Kualitas Air Tanah Pada Akuifer Tertekan Cekungan Air Tanah Baubau Di Kota Baubau
}

\section{Determination of Recharge Areas and Evaluation of Groundwater Quality in Confined Aquifers of Baubau Groundwater Basin in Baubau City}

\author{
Wahyu Hidayat ${ }^{1 *}$, Laode Sabaruddin ${ }^{2)}$, La Baco ${ }^{3)}$ \\ ${ }^{1)}$ Programstudi Magister Perencanaan Pengembangan Wilayah, Universitas Halu Oleo \\ 2) Jurusan Ilmu Tanah, Universitas Halu Oleo \\ ${ }^{3)}$ Programstudi Magister Perencanaan Pengembangan Wilayah, Universitas Halu Oleo
}

\begin{abstract}
The increasing population followed by the development of industrial activities resulted in excessive exploitation of water and pollution of water sources. This research aims (1) to analyze the distribution of groundwater recharge areas, (2) to analyze the quality of groundwater; and (3) to analyze the effect of seawater intrusion on the Baubau CAT confined aquifer within the City of Baubau area. The analysis method used is (1) Determination of groundwater recharge areas is carried out based on Permen ESDM Number 31 of 2018 concerning Guidelines for Establishing Groundwater Conservation Zones, namely by identifying hydrogeological data, (2) The level of groundwater damage is analyzed based on groundwater quality, in accordance with ESDM Ministerial Regulation Number 31 of 2018 concerning Guidelines for Establishing Groundwater Conservation Zones; and (3) The level of seawater intrusion was classified using the Davis and de Weist method. The results of this study are (1) The distribution of recharge areas covers $43 \%$ of the land area of the City of Baubau or an area of $96 \mathrm{~km}^{2}$. The recharge area is an area of low hills, hills and high hills with an altitude of 100 to 700 meters above sea level. (2) The level of groundwater damage based on TSD and DHL values is that there are 7 drilled wells that are still in the safe category, while the other 2 bore wells are in the vulnerable category; (3) Groundwater in confined aquifers in the study area has not shown the influence of sea water intrusion with DHL values ranging from $773 \mu \mathrm{S} \mathrm{cm}{ }^{-1}$ to $1,402 \mu \mathrm{S} \mathrm{cm}^{-1}$ and is categorized as fresh groundwater where the DHL values are still in the range of $30-2,000 \mu \mathrm{S} \mathrm{cm}{ }^{-1}$.
\end{abstract}

Keywords: Groundwater, Groundwater Quality, Seawater Intrusion

\begin{abstract}
ABSTRAK
Jumlah penduduk yang meningkat dan diikuti dengan berkembangnya aktivitas industri mengakibatkan eksploitasi air berlebih dan pencemaran sumber air. Peneltian ini bertujuan (1) untuk menganalisis sebaran daerah imbuhan air tanah, (2) menganalisis kualitas air tanah; dan (3) menganalisis pengaruh intrusi air laut pada akuifer tertekan CAT Baubau dalam wilayah Kota Baubau. Metode analisis yang digunakan yaitu (1) Penentuan daerah imbuhan air tanah dilakukan berdasarkan Permen ESDM Nomor 31 Tahun 2018 Tentang Pedoman Penetapan Zona Konservasi Air Tanah yaitu dengan melakukan identifikasi data hidrogeologi, (2) Tingkat kerusakan air tanah dianalisa berdasarkan kualitas air tanah, sesuai dengan Permen ESDM Nomor 31 Tahun 2018 Tentang Pedoman Penetapan Zona Konservasi Air Tanah; dan (3) Klasifikasi tingkat intrusi air laut dilakukan dengan metode Davis and de Weist. Hasil penelitian ini yaitu (1) Sebaran daerah imbuhan tersebut meliputi $43 \%$ dari luas daratan Kota Baubau atau seluas $96 \mathrm{~km}^{2}$. Daerah imbuhan tersebut merupakan wilayah perbukitan rendah, perbukitan dan perbukitan tinggi dengan ketinggian 100 hingga 700 meter di atas permukaan laut. (2) Tingkat kerusakan air tanah berdasarkan nilai TSD dan DHL adalah terdapat 7 sumur bor masih dalam kategori aman, sedangkan 2 sumur bor lainnya masuk dalam kategori rawan; (3) Air tanah pada akuifer tertekan di daerah penelitian belum memnunjukkan adanya pengaruh intrusi air laut dengan nilai DHL berkisar antara $773 \mu \mathrm{S} \mathrm{cm}^{-1}$ hingga $1.402 \mu \mathrm{S} \mathrm{cm}^{-1}$ dan dikategorikan sebagai air tanah segar dimana nilai DHL masih berada dalam kisaran $30-2.000 \mu \mathrm{S} \mathrm{cm}$.
\end{abstract}

Kata Kunci : Air Tanah, Kualitas Air Tanah, Intrusi Air Laut 


\section{PENDAHULUAN}

Amanat Undang-Undang Dasar Negara Republik Indonesia Tahun 1945 bahwa dalam menghadapi ketidakseimbangan antara ketersediaan air yang cenderung menurun dan kebutuhan air yang semakin meningkat, sumber daya air perlu dikelola dengan memperhatikan fungsi sosial, lingkungan hidup, dan ekonomi secara selaras untuk mewujudkan sinergi dan keterpaduan antarwilayah, antarsektor, dan antargenerasi guna memenuhi kebutuhan ralgrat atas air (UU No. 17 Tahun 2019 Tentang Sumberdaya Air).

Kota Baubau berada di Pulau Buton yang terletak di Sebelah Tenggara Pulau Sulawesi yang merupakan bagian dari wilayah negara Indonesia. Secara astronomi Kota Baubau berada pada posisi koordinat $5^{0} 21^{\prime}-5^{0} 30^{\prime}$ Lintang Selatan dan diantara $122^{\circ} 30^{\prime}-122^{\circ} 45^{\prime}$ Bujur Timur. Wilayah Kota Baubau merupakan bagian dari Cekungan Air Tanah (CAT) Baubau. Pesatnya pembangunan di Kota Baubau menyebabkan bertambahnya kebutuhan hidup, termasuk kebutuhan akan sumberdaya lahan dan kebutuhan akan air besih. Kebutuhan lahan dikawasan perkotaan yang semakian meningkat sejalan dengan pertumbuhan penduduk dan kegiatan sosial ekonomi yang menyertainya akan berdampak pada pengurangan ketersediaan air.

Pemenuhan kebutuhan akan air semakin meningkat, maka dilakukan upaya pengeksploitasian air tanah sebagai pengganti air permukaan yang debitnya cenderung menurun di musim kemarau dan akibat perubahan tata guna lahan sumber air permukaan menjadi berkurang. Oleh karena itu diperlukan manajemen atau pengelolaan air tanah sebagai solusi sekaligus sebagai pencegahan dan penyelesaian masalah atau konflik.

Kota Baubau mempunyai wilayah daratan seluas 221,00 km² dan luas laut mencapai $30 \mathrm{~km}^{2}$. Sebelah Utara Kota Baubau berbatasan langsung dengan Selat Buton, dengan panjang garis pantai + $42 \mathrm{Km}$ (Pemerintah Kota Baubau, 2017). Karakteristik ketersediaan air tawar di wilayah pesisir secara kuantitas umumnya memiliki air yang berlimpah, tetapi seringkali sulit mendapatkan air untuk berbagai penggunaan karena kualitasnya yang kurang memadai, namun di wilayah pesisir lain seringkali terdapat kesulitan untuk mendapatkan sumberdaya air tawar. Pengaruh laut terhadap tata air seringkali terlihat signifikan di wilayah pesisir, namun pengaruh tersebut berbeda di satu tempat dan tempat yang lain (Delinom, 2007). Sumber mata air terbesar di Kota Baubau berada di Kecamatan Bungi, Kecamatan Kokalukuna, Kecamatan Laea, Kecamatan Sorawalio, dan Kecamatan Betoambari (Harimu, dkk, 2019)

Berdasarkan data BPS Kota Baubau 2018, jumlah penduduk Kota Baubau di tahun 2010 sebanyak 137.715 jiwa dan di tahun 2016 menunjukkan angka 158.271 jiwa $(2,16 \%)$. Jumlah industri/perusahaan pada tahun 2011 adalah 1.548 perusahaan dan pada tahun 2015 meningkat menjadi 1.818 perusahaan. Peningkatan pertumbuhan penduduk dan industri di Kota Baubau menuntut pengeksploitasian air tanah serta pemanfaatan lahan. Akibatnya sangat berpengaruh terhadap perubahan kuantitas dan kualitas air tanah dan mengakibatkan terganggunya daerah resapan atau imbuhan air tanah.

Perkembangan industri dan peningkatan jumlah penduduk akan menimbulkan eksploitasi air yang berlebihan dan pencemaran sumber air akibat limbah yang tidak dikelola dengan baik. $\mathrm{PH}$ ada air dipengaruhi oleh keberadaan dilimbah dan jenis pencemarnya (Supangat, 2008). Pada daerah imbuhan air tanah, air permukaan akan meresap secara alamiah dimana tidak semua daerah memiliki karakteristik dan fungsi seperti daerah imbuhan tersebut. Air tanah yang merupakan sumber utama air bersih penduduk lambat laun akan mulai tercemar oleh limbah-limbah berbahaya bagi kesehatan dan pada kawasan industri, air tanah rawan terjadi pencemaran oleh limbah sisa hasil produksi. Hal tersebut sangat berpengaruh terhadap perubahan kualitas air tanah. Tujuan dari penelitian ini yaitu 1) menganalisis sebaran daerah imbuhan air tanah pada CAT Baubau dalam wilayah Kota Baubau; 2) menganalisis kualitas air tanah pada akuifer tertekan CAT Baubau dalam wilayah Kota Baubau; dan 3) menganalisis pengaruh intrusi air laut pada akuifer tertekan CAT Baubau dalam wilayah Kota Baubau.

\section{METODE PENELITIAN}

\section{Lokasi Penelitian}

Lokasi penelitian berada dalam Cekungan Air Tanah (CAT) Baubau dalam wilayah administrasi Kota Baubau (Gambar 1), dengan azsumsi bahwa pelaksanaan konservasi air tanah dilakukan dalam suatu Cekungan Air Tanah 
(Permen ESDM Nomor 31 Tahun 2018). Penentuan lokasi penelitian yaitu dengan melihat keunikan kondisi hidrogeologinya. Penentuan lokasi penelitian juga mempertimbangkan perolehan data yang dibutuhkan untuk tercapainya tujuan penelitian.

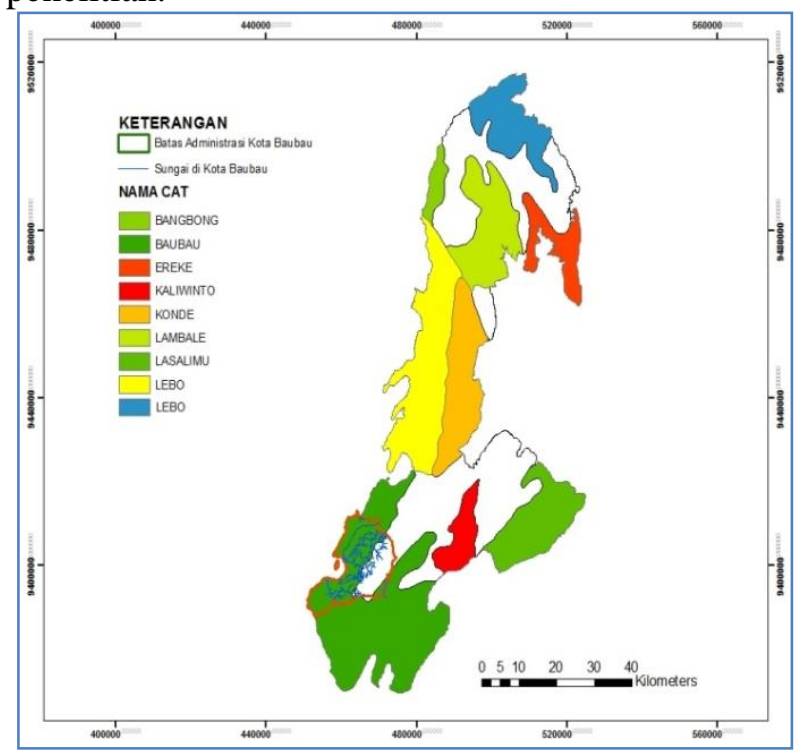

Gambar 1. Peta pembagian CAT Pulau Buton dan Lokasi Penelitian

Berdasarkan keterdapatan air tanah dan produktifitas akuifernya, CAT Baubau terdiri dari (Setiadi dkk., 1993) (a) Setempat, akuifer produktifitas sedang; (b) Akuifer dengan produktivitas sedang; (c) Setempat akuifer produktif; (d) Akuifer dengan produktifitas rendah, setempat berarti; dan (e) Daerah air tanah langka.

\section{Populasi dan Sampel}

Populasi dalam pengambilan data kualitas air tanah adalah air tanah pada akuifer tertekan yang berada pada CAT Baubau di wilayah Kota Baubau sesuai dengan Permen ESDM No. 2 Tahun 2017 tentang Cekungan Air Tanah di Indonesia. Secara umum, air tanah dapat dikumpulkan melalui sumursumur, terowongan atau sistem drainase atau dengan pemompaan (Freeze and Cherry, 1979).

Sampel dalam penelitian ini adalah air tanah pada akuifer tertekan yang belum mengalami pengolahan pada beberapa sumur bor produksi di Kota Baubau. Terdapat sembilan titik sumur bor produksi di Kota Baubau yang berada dibawah pengawasan Dinas Energi dan Sumber Daya Mineral (ESDM) Provinsi Sulawesi Tenggara. Kesembilan titik sumur bor produksi tersebut akan dijadikan sampel penelitian.

\section{Variable Penellitian}

a. Variabel Penentuan Daerah Imbuhan Air Tanah

Variabel yang digunakan dalam penentuan daerah imbuhan air tanah adalah : (a) Deliniasi wilayah CAT Baubau; (b) Topografi daerah CAT Baubau; dan (c) Pola aliran sungai daerah CAT Baubau.

\section{b. Variabel Penentuan Kualitas Air Tanah}

Variabel yang digunakan dalam melakukan analisa kualitas air tanah adalah jumlah zat padat terlarut (TDS), Daya Hantar Listrik (DHL), dan $\mathrm{pH}$ air tanah. Parameter tersebut akan digunakan dalam klasifikasi air tanah dan untuk menentukan tingkat intrusi air laut.

\section{Teknik Analisis Data}

\section{a. Metode Analisis Data Penentuan Daerah Imbuhan Air Tanah}

Penentuan daerah imbuhan air tanah dilakukan berdasarkan Permen ESDM Nomor 31 Tahun 2018 Tentang Pedoman Penetapan Zona Konservasi Air Tanah yaitu dengan melakukan identifikasi data hidrogeologi yaitu penentuan daerah imbuhan air tanah berdasarkan tekuk lereng dan pola aliran sungai. Penentuan daerah imbuhan air tanah tersebut dilakukan dengan menggunakan softwaresystem informasi geografis. Peta yang dibutuhkan yaitu peta kontur, Peta Hidrogeologi

\section{b. Metode Analisis Data Tingkat Kerusakan Air Tanah}

Tingkat kerusakan air tanah dianalisa berdasarkan kualitas air tanah, sesuai dengan Permen ESDM Nomor 31 Tahun 2018 Tentang Pedoman Penetapan Zona Konservasi Air Tanah. Klasifikasi tingkat kerusakan air tanah adalah sebagai berikut : a) Aman : penurunan kualitas yang ditandai oleh kenaikan zat padat terlarut (ZPT) atau dikenal dengan total dissolved solid (TDS) menjadi kurang dari $1.000 \mathrm{mg}^{-1}$ atau DHL $<1.000 \mu \mathrm{S} / \mathrm{Cm}$; b) Rawan: penurunan kualitas yang ditandai oleh kenaikan ZPT menjadi antara 1.000 s.d $10.000 \mathrm{mg} / \mathrm{L}$ atau DHL 1.000 s.d 1.500 $\mu \mathrm{S} / \mathrm{Cm}$; dan c) Kritis : penurunan kualitas yang ditandai oleh kenaikan ZPT menjadi lebih dari 10.000 s.d $100.000 \mathrm{mg} / \mathrm{L}$ atau DHL > 1.500 s.d $5.000 \mu \mathrm{S} / \mathrm{Cm}$.

Klasifikasi tingkat intrusi air laut dilakukan dengan metode Davis and de Weist (1966), berdasarkan jumlah konsentrasi unsur terlarut. Secara alami dikenal 7 ion mayor yang dapat larut dalam air yaitu : $\mathrm{Ca}^{2+}$ (Kalsium), $\mathrm{K}^{+}$(Kalium), 
$\mathrm{Mg}^{2+}$ (Magnesium), $\mathrm{Na}^{2+}$ (Natrium), $\mathrm{Cl}$ (Clorida), $\mathrm{HCO}_{3}{ }^{-}$(bikarbonat), dan $\mathrm{SO}_{4}$ (Sulfat). Unsur ion mayor ini selalu digunakan dalam penyajian data kimia air tanah. (Irawan dan Puradimaja, 2015). Untuk penyajian hasil analisis kimia air tanah, umumnya dipakai Diagram Trilinier Piper (Sutandi, 2012).

\section{HASIL DAN PEMBAHASAN}

CAT Baubau menempati wilayah Kota Baubau yang tersusun oleh batuan sedimen. Berdasarkan Peta Geologi Regional Lembar Buton,
Sulawesi Tenggara (Sikumbang, dkk.,1995), beberapa batuan penyusun pada CAT Baubau dalam wilayah Kota Baubau adalah berupa batuan sedimen dan sebagian kecil batuan beku. Batuan tertua berumur pra-Trias, sedangkan batuan termuda berumur Resen. Susunan batuan dari yang paling tua hingga yang paling muda yaitu, Formasi Mukito (PTRm), Formasi Winto (Trw), Formasi Ogena (Jo), Diorit (Di), Komplek Ultrabasa Kapantoreh (Tuck), Anggota Batugamping Formasi Tondo (Tmtl), Formasi Tondo (Tmtc), Formasi Sampolakosa (Tmps), Formasi Wapulaka (Qpw), dan Aluvium (Qal) (Gambar 2).

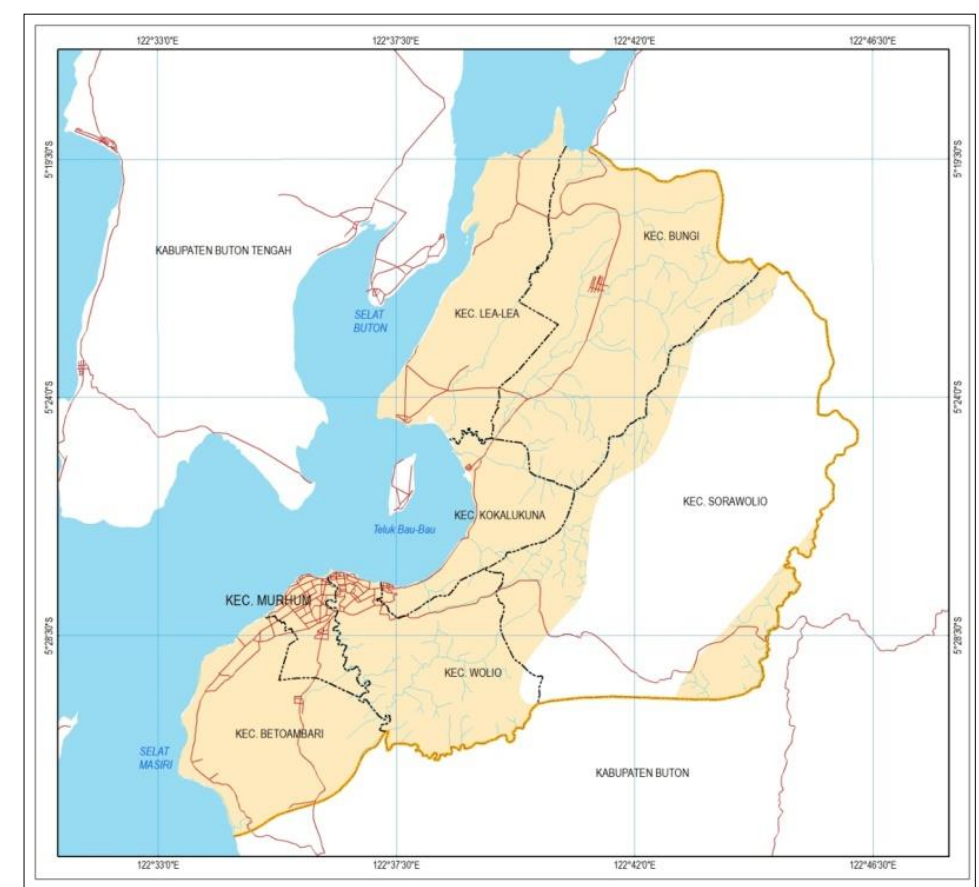

Gambar 2. Peta CAT Baubau dalam wilayah Kota Baubau

Secara umum CAT Baubau di daerah penelitian tersusun oleh batuan sedimen, yaitu satuan Aluvium, Formasi Wapulaka, Formasi Sampolakosa, sebagian Formasi Tondo dan Anggota Batugamping Formasi Tondo, dan sebagian Formasi Winto, serta jenis batuan beku Diorit dan sebagian kecil batuan beku Ultrabasa. Dari beberapa formasi batuan sedimen dan batuan beku di daerah penelitian, sebaran CAT Baubau tidak menempati batuan Formasi Mukito, batuan Formasi Ogena, sebagian Formasi Winto, sebagian Formasi Tondo, serta sebagian besar batuan beku Ultrabasa. Formasi batuan sedimen dalam CAT Baubau merupakan batuan sedimen yang memiliki tekstur klastika dengan ukuran butir lempung, pasir hingga kerakal.
Batuan sedimen merupakan batuan yang memiliki potensi porositas yang sangat berperan dalam menampung kandungan fluida termasuk air tanah dalam suatu massa batuan. Batuan sedimen yang berukuran pasir hingga kerakal merupakan batuan sedimen yang memiliki porositas dan permeabilitas yang cukup baik. Porositas (kemampuan lapisan batuan untuk menyimpan air) dan permeabilitas (kemampuan batuan untuk meluluskan air) merupakan variabel utama dalam proses hidrogeologis, khususnya pada proses pengimbuhan, dan pengaliran serta sebagai lapisan akuifer. Disamping memiliki porositas dan permeabilitas yang baik, batuan sedimen di daerah penelitian juga tersusun oleh batuan berukuran lempung dan lanau yang bersifat kedap air atau 
impermeabel. Lapisan batuan semacam ini merupakan jenis batuan yang tidak tembus air yang berperan sebagai lapisan pembatas pada akuifer tertekan.

$$
\text { Batuan sedimen yang memiliki }
$$

permeabilitas yang tinggi karena butiran penyusunnya seragam dengan ukuran butir kasar dan berupa sedimen lepas dapat bertindak sebagai akuifer yang baik (Kodoatie, R.J., 2012). Akuifer tertekan memiliki batas lapisan atas dan bawah berupa formasi batuan yang tidak tembus air (Bear, 1979). Batuan beku Diorit dan sebagian batuan Ultrabasa merupakan batuan penyusun dalam daerah sebaran imbuhan air tanah di wilayah penelitian. Batuan beku merupakan batuan yang terbentuk dari proses pembekuan magma. Pada dasarnya batuan beku bukan merupakan batuan yang baik untuk menampung fluida karena jenis batuan beku, khususnya Diorit dan Ultrabasa tidak miliki pori. Akan tetapi, rekahan-rekahan pada batuan beku yang terbentuk akibat gaya struktur geologi mengakibatkan batuan tersebut memiliki rongga-rongga yang dapat menampung dan mengalirkan air tanah.

Batuan beku umumnya padat, tidak berpori, keras, dapat menahan air dalam jaringan rekahan, kekar, retakan atau patahan atau sepanjang kontak dengan batuan jenis lain disekitarnya, seperti dalam bentuk dike dan sill. Pada kondisi iklim tertentu, batuan ini akan mengalami pelapukan sehingga kondisinya memungkinkan untuk proses infiltrasi dan imbuhan tanah air (UNESCO, 1984).

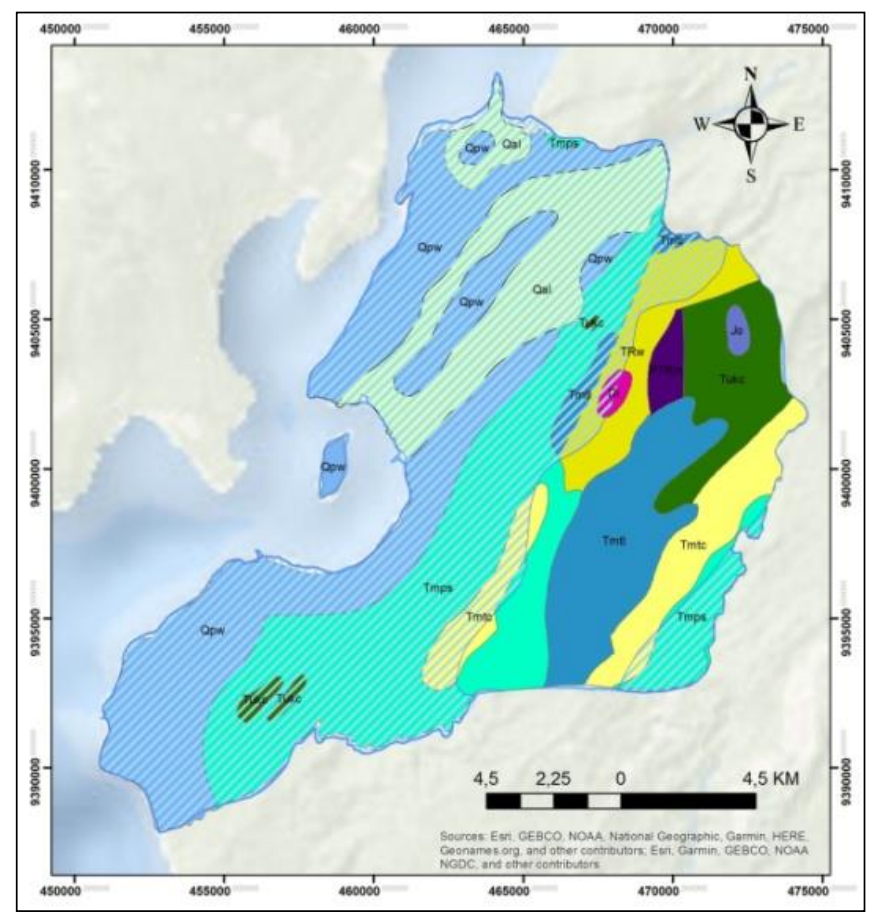

Gambar 3. Peta litologi dan Cekungan Air Tanah Kota Baubau

\section{Dearah Imbuhan Air Tanah}

CAT Baubau adalah bagian dari beberapa CAT yang ada di Provinsi Sulawesi Tenggara yang pembagiannya diatur dalam Peraturan Menteri ESDM No. 2 Tahun 2017 Tentang Cekungan Air Tanah di Indonesia. Daerah imbuhan dalam wilayah kota Baubau merupakan bagian dari daerah CAT Baubau. Dengan menerapkan metode analisa tekuk lereng dan analisa pola aliran sungai, dilakukan deliniasi daerah imbuhan air tanah dimana daerah imbuhan tersebut meliputi $43 \%$ dari luas wilayah daratan Kota Baubau atau seluas $96 \mathrm{~km}^{2}$. Daerah imbuhan air tanah pada CAT Baubau dalam wilayah Kota Baubau secara umum menempati wilayah perbukitan pedalaman, perbukitan dan perbukitan tinggi (Gambar 3).

Sebaran daerah imbuhan berdasarkan analisa tekuk lereng dicirikan dengan batas antara morfologi pedataran dan perbukitan. Daerah imbuhan secara sederhana merupakan daerah yang berada di atas tekuk lereng atau dapat dikatakan berada di atas daerah pedataran. Jika diproyeksikan ke dalam klasifikasi morfologi berdasarkan van Zuidam (1985), maka daerah imbuhan air tanah di daerah penelitian meliputi wilayah perbukitan rendah, perbukitan, hingga perbukutan tinggi 
dengan ketinggian 100 hingga 700 meter di atas permukaan laut. Berdassarkan analisa pola aliran sungai, sebaran daerah imbuhan di daerah penelitian menempati morfologi kawasan yang dicirikan oleh beberapa anak sungai yang relatif pendek. Daerah imbuhan tersebut ditempati oleh sungai orde ketiga dan keempat.

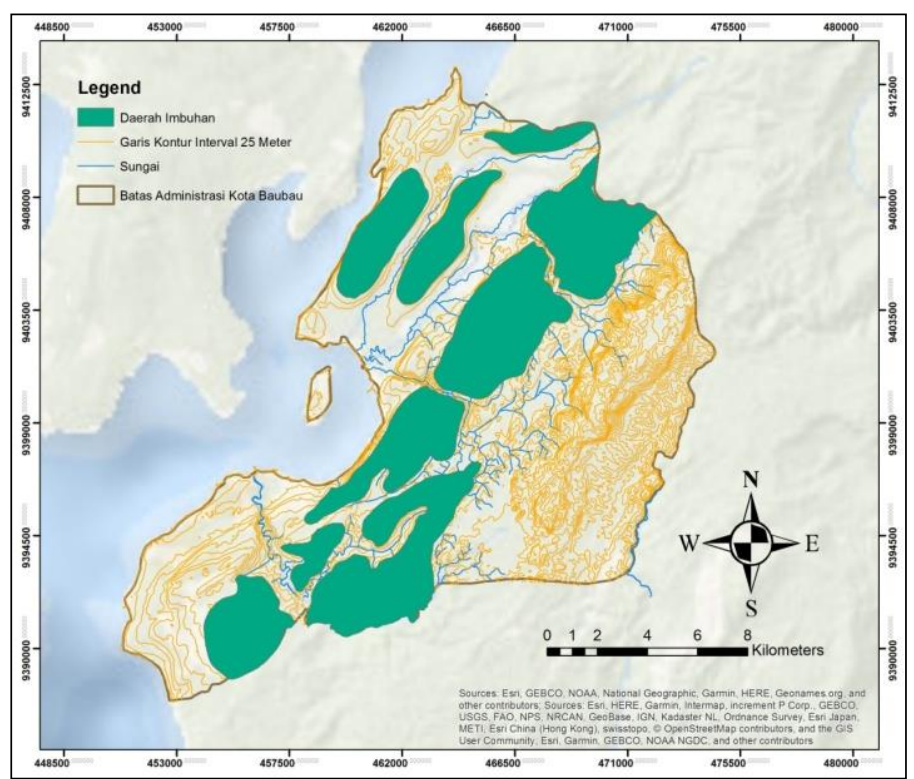

Gambar 3. Morfologi sebaran daerah imbuhan air tanah Kota Baubau

Daerah imbuhan air tanah daerah penelitian merupakan daerah yang berfungsi sebagai daerah resapan alamiah yang mempunyai karakteristik hidrogeologi tertentu yang merupakan daerah pengisian air tanah pada CAT Baubau. Imbuhan air tanah merupakan parameter hidrologi penting yang sangat bergantung pada skala spasial dan waktu. Berdasarkan analisa peta geologi, maka secara umum, sebaran daerah imbuhan tersusun oleh batuan sedimen (Gambar

4).

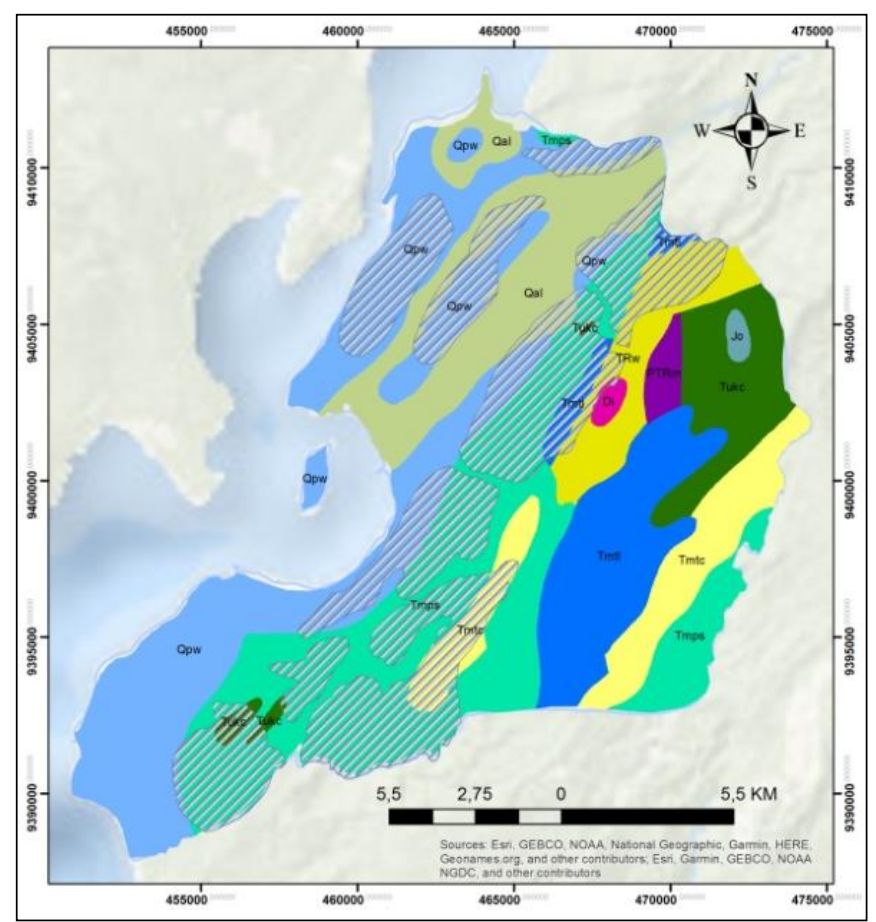

Gambar 4. Peta litologi dan daerah imbuhan Kota Baubau 


\section{Kualitas Air Tanah}

Pengamatan kulaitas air tanah dilakukan pada sumur bor di daerah penelitian. Sampel yang dianalisa adalah air tanah pada akuifer tertekan pada kedalaman 26 hingga 66 meter. Hasil observasi sumur bor pengamatan di lapangan didapatkan 9 lokasi sumur bor (Tabel 1). Sumur bor pengamatan merupakan sumur produksi yang pemanfaatannya digunakan untuk pengusahaan air tanah, dengan debit pemakaian air tanah 0,4 liter/detik hingga 1,0 liter/detik atau setara dengan 10,8 kubik/hari hingga 28,80 kubik/hari (Tabel 2). Berdasarkan Peraturan Menteri Energi dan Sumber Daya Mineral Nomor 20 Tahun 2017 tentang Pedoman Penetapan Nilai Perolehan Air Tanah, Sumur bor pengamatan merupakan komponen peruntukan dan pengelolaan air tanah dalam bentuk pengusahaan industri air minum dalam kemasan.

Tabel 1. Kualitas Air Tanah Pada Daerah Penelitian

\begin{tabular}{|l|l|l|l|l|l|c|r|r|}
\hline Kode & \multicolumn{2}{|c|}{ Koordinat } & Jenis Sumur & Bau Rasa & $\begin{array}{c}\text { TDS } \\
\left(\mathrm{mg}^{-1}\right)\end{array}$ & $\begin{array}{c}\text { DHL } \\
\left(\mu \mathrm{cm}^{-1}\right)\end{array}$ & $\mathrm{pH}$ \\
\hline P1 & 122,611037 & $-5,4628932$ & Sumur Bor & tb & tr & 141 & 945 & 7,2 \\
\hline P2 & 122,578464 & $-5,48101111$ & Sumur Bor & tb & tr & 165 & 880 & 7,6 \\
\hline P3 & 122,619944 & $-5,46049444$ & Sumur Bor & tb & tr & 227 & 890 & 7,7 \\
\hline P4 & 122,59939 & $-5,46774$ & Sumur Bor & tb & tr & 109 & 834 & 7,4 \\
\hline P5 & 122,662639 & $-5,39830556$ & Sumur Bor & tb & tr & 172 & 1138 & 7,3 \\
\hline P6 & 122,630694 & $-5,40613889$ & Sumur Bor & tb & tr & 136 & 866 & 7,2 \\
\hline P7 & 122,619069 & $-5,46068056$ & Sumur Bor & tb & tr & 212 & 1402 & 7,8 \\
\hline P8 & 122,56599 & $-5,49417$ & Sumur Bor & tb & tr & 139 & 773 & 8 \\
\hline P9 & 122,576639 & $-5,47966667$ & Sumur Bor & tb & tr & 104 & 786 & 7,1 \\
\hline Keteran
\end{tabular}

Keterangan : $\mathrm{tb}=$ Tidak Berbau

$\mathrm{Tr}=$ Tidak Berasa

Sumber: Hasil Pegolahan Data, 2021

Tabel 2. Pemanfaatan Air Tanah Pada Titik Pengamatan

\begin{tabular}{|c|c|c|c|c|c|c|}
\hline \multirow[t]{2}{*}{ Kode } & \multicolumn{2}{|c|}{ Kedalaman (m) } & \multirow{2}{*}{$\begin{array}{l}\text { Jenis Akuifer } \\
\text { (Sumber : Dinas } \\
\text { ESDM Prov. } \\
\text { Suktra, 2016) }\end{array}$} & \multirow{2}{*}{$\begin{array}{c}\text { Debit } \\
\text { Pemompaan } \\
\text { (liter/detik) }\end{array}$} & \multirow{2}{*}{$\begin{array}{c}\text { Lamanya } \\
\text { Operasional } \\
\text { Pemompaan } \\
\text { (jam/hari) }\end{array}$} & \multirow{2}{*}{$\begin{array}{c}\text { Volume } \\
\text { Pengambi } \\
\text { lan Air } \\
\left(\mathrm{m}^{3} / \mathrm{hari}\right) \\
\end{array}$} \\
\hline & Sumur Bor & Akuifer & & & & \\
\hline $\mathrm{P} 1$ & 48 & $44-47$ & Tertekan & 0,5 & 11 & 19,8 \\
\hline $\mathrm{P} 2$ & 60 & $42-46$ & Tertekan & 0,4 & 11 & 15,84 \\
\hline P3 & 80 & $60-66$ & Tertekan & 0,4 & 8 & 11,52 \\
\hline $\mathrm{P} 4$ & 54 & $46-50$ & Tertekan & 0,43 & 11 & 17,028 \\
\hline P5 & 30 & $26-29$ & Tertekan & 0,5 & 6 & 10,8 \\
\hline P6 & 43 & $38-42$ & Tertekan & 0,4 & 8 & 11,52 \\
\hline $\mathrm{P7}$ & 36 & $31-35$ & Tertekan & 0,4 & 8 & 11,52 \\
\hline P8 & 47 & $43-46$ & Tertekan & 1 & 8 & 28,8 \\
\hline P9 & 39 & $34-38$ & Tertekan & 1 & 8 & 28,8 \\
\hline
\end{tabular}

Sumber: Hasil Pegolahan Data, 2021

\section{Tingkat Kerusakan Air Tanah}

Analisa serta peniulaian tingkat kerusakan air tanah di wilayah penelitian mengacu pada PERMEN ESDM No. 31 Tahun 2018 tentang Pedoman Penetapan Zona Konservasi Air Tanah (Tabel 3).

Tabel 3. Tingkat Kerusakan Air Tanah Pada Akuifer Tertekan Maupun Akuifer Tidak Tertekan Berdasarkan Kualitas Air Tanah

\begin{tabular}{lll}
\hline Kategori & TDS $\left(\mathbf{m g ~ l}^{-1}\right)$ & DHL $\left(\boldsymbol{\mu S ~ \mathbf { ~ m } ^ { - 1 } )}\right.$ \\
\hline Aman & $<1.000$ & $<1.000$ \\
Rawan & $1.000-10.000$ & $1.000-1.500$ \\
\hline
\end{tabular}

\begin{tabular}{lll}
\hline Kategori & TDS $\left(\mathrm{mg} \mathrm{l}^{-1}\right)$ & DHL $\left(\boldsymbol{\mu S ~ ~ m ^ { - 1 }}\right)$ \\
\hline Kritis & $10.000-100.000$ & $1.500-5.000$ \\
Rusak & & \\
\hline
\end{tabular}

Sumber : PERMEN ESDM No. 31 Tahun 2018

Hasil pengukuran di lapangan menunjukkan bahwa nilai TDS air tanah tertekan di daerah penelitian berkisar antara $104 \mathrm{mg} \mathrm{1^{-1 }}$ hingga $227 \mathrm{mg}$ $1^{-1}$. Sedangkan nilai DHL air tanah tertekan di daerah penelitian berkisar antara $773 \mu \mathrm{S} \mathrm{cm} \mathrm{cm}^{-1}$ hingga $1.402 \mu \mathrm{S} \mathrm{cm} \mathrm{cm}^{-1}$. Berdasarkan klasifikasi tingkat kerusakan air tanah (PERMEN ESDM No. 
31 Tahun 2018), maka tingkat kerusakan air tanah pada daerah penelitian berdasarkan nilai TSD dan DHL adalah terdapat 7 sumur bor masih dalam kategori aman, yaitu sumur P1, P2. P3. P4, P6, P8 dan $\mathrm{P} 9$, sedangkan 2 sumur bor lainnya masuk dalam kategori rawan, yaitu sumur P5 dan P7 Secara adminsitrasi, sebaran sumur bor yang menjadi titik pengamatan berada Kecamatan Betoambari, Kecamatan Murhum, Kecamatan Wolio, Kecamatan Bungi dan Kecamatan Lea-Lea (Tabel 4).
Sumur P5 dan P7 merupakan sumur bor produksi yang memanfaatkan air tanah pada akuifer tertekan sebagai air baku, atau dikatakan sebagai sumur yang pemanfaatannya sebagai pengusahaan air tanah. Kedalaman sumur P5 adalah 39 meter dan menyadap air tanah pada kedalaman akuifer $26-29$ meter, dengan ketebalan akuifer tiga meter. Sumur P7 memeiliki kedalaman 36 meter, dengan kedalaman akuifer yang disadap atau dimanfaatkan adalah 31 - 35 meter atau memiliki ketebalan akuifer empat meter.

Tabel 4. Klasifikasi tingkat kerusakan air tanah wilayah penelitian

\begin{tabular}{cccccccc}
\hline Kode & \multicolumn{2}{c}{$\begin{array}{c}\text { Kedalaman } \\
\text { (meter) }\end{array}$} & $\begin{array}{c}\text { Lokasi } \\
\text { Kecamatan }\end{array}$ & $\begin{array}{c}\text { Pengambilan } \\
\text { air } \\
\left(\mathrm{m}^{3} / \text { hari }\right)\end{array}$ & $\begin{array}{c}\text { TDS } \\
\left(\mathrm{mg} \mathrm{l}^{-1}\right)\end{array}$ & $\begin{array}{c}\text { DHL } \\
\left(\mu \mathrm{S} \mathrm{cm}^{-1}\right)\end{array}$ & Kategori \\
\hline P1 & 48 & $44-47$ & Wolio & 19,8 & 141 & 945 & Aman \\
P2 & 60 & $42-46$ & Betoambari & 15,84 & 165 & 880 & Aman \\
P3 & 80 & $60-66$ & Wolio & 11,52 & 227 & 890 & Aman \\
P4 & 54 & $46-50$ & Murhum & 17,028 & 109 & 834 & Aman \\
P5 & 30 & $26-29$ & Bungi & 10,8 & 172 & 1138 & Rawan \\
P6 & 43 & $38-42$ & Lea-Lea & 11,52 & 136 & 866 & Aman \\
P7 & 36 & $31-35$ & Murhum & 11,52 & 212 & 1402 & Rawan \\
P8 & 47 & $43-46$ & Betoambari & 28,8 & 139 & 773 & Aman \\
P9 & 39 & $34-38$ & Betoambari & 28,8 & 104 & 786 & Aman \\
\hline
\end{tabular}

Sumber: Hasil Pegolahan Data, 2021

Air tanah pada sumur P5 dan P7 dicirikan dengan tingginya nilai DHL yaitu $1138 \mu \mathrm{S} \mathrm{cm} \mathrm{cm}^{-1}$ dan 1402 $\mu \mathrm{S} \mathrm{cm}^{-1}$. DHL atau konduktivitas merupakan gambaran numerik dari kemampuan air untuk meneruskan aliran listrik. Semakin banyak garam terlarut yang dapat terionisasi, maka semakin tinggi pula nilai DHL-nya. DHL erat kaitannya dengan nilai salinitas suatu perairan. Semakin tinggi nilai salinitas suatu perairan makan semakin tinggi pula nilai DHL-nya.

Titik pengamatan pada sumur P5 dan P7 berada pada wilayah komersil (Peta Pola Ruang Kota Baubau tahun 2014 - 2034) dan secara administrasi sumur P5 berada pada wilayah Kecamatan Bungi dan sumur P7 berada pada wilayah Kecamatan Murhum (Tabel 5.).

Tabel 5. Titik Pengamatan dalam Wilayah Pola Ruang dan Admnsitrasi Kota Baubau

\begin{tabular}{llcr}
\hline Kode & \multicolumn{1}{c}{$\begin{array}{c}\text { Pola Ruang } \\
(\mathbf{2 0 1 4}-\mathbf{2 0 3 4 )}\end{array}$} & Kecamatan & \multicolumn{2}{c}{$\begin{array}{c}\text { Kepadatan Penduduk } \\
\mathbf{( 2 0 2 0 )}\end{array}$} \\
\hline P1 & Pemukiman & Wolio & $1.255,03$ \\
P2 & Komersil & Betoambari & 607,62 \\
P3 & Komersil & Wolio & $1.255,03$ \\
P4 & Pemukiman & Murhum & $3.351,06$ \\
P5 & Komersil & Bungi & 142,84 \\
P6 & Pemukiman & Lea-Lea & 226,41 \\
P7 & Komersil & Murhum & $3.351,06$ \\
P8 & Kawasan Bandara & Betoambari & 607,62 \\
P9 & Kawasan Bandara & Betoambari & 607,62 \\
\hline
\end{tabular}

Sumber: Hasil Pegolahan Data, 2021 
Berdasarkan sebaran litologi permukaan, sumur P1, P2, P3,P4, P5, P6, P7 dan P8 berada pada litologi Formasi Wapulaka (Qpw). Formasi Wapulaka terdiri dari batugamping terumbu ganggang dan koral, endapan hancuran terumbu, batukapur, batugamping pasiran, batupasir gampingan, batulempung dan napal kaya foraminifera plangton, tebal satuan diperkirakan 700 meter. Sumur P9 berada pada satuan Aluvium (Qal) yang terdiri dari kerikil, kerakal, pasir lumpur dan gambut, hasil endapan sungai, rawa dan pantai.

\section{Klasifikasi Air Tanah}

\section{a. Konsentrasi Total Dissolve Solid (TDS)}

Konsentrasi TDS dalam air tanah bervariasi. Perlu dicatat bahwa air yang mengandung TDS lebih dari 2000-3000 mg /1 umumnya asin untuk diminum. TDS air laut sekitar $35.000 \mathrm{mg}^{-1}$ (Freeze and Cherry, 1979). Konsentrasi zat pada terlarut pada air tanah dipengaruhi oleh beberapa hal, diantaranya adalah kondisi lingkungan yang dilewati oleh air serta kondisi litologi dimana tempat air itu berada (akuifer). Setiap air tanah memiliki nilai TDS yang berbeda-beda tergantung dari jumlah konsentrasi ion-ion terlarut di dalamnya (Tabel 6).

Tabel 6. Klasifikasi air tanah berdasarkan kandungan unsur terlarut (Davis dan de Weist, 1966)

\begin{tabular}{ll}
\hline \multicolumn{1}{c}{ Jenis Air } & \multicolumn{1}{c}{$\begin{array}{c}\text { Konsentrasi Kandungan Unsur Terlarut } \\
\left(\mathrm{mg} \mathrm{l}^{-1} \text { atau } \mathrm{g} \mathrm{m}^{-3}\right)\end{array}$} \\
\hline Air tawar (fresh water) & $0-1.000$ \\
Payau (brackish water) & $1.000-10.000$ \\
Air asin (saline water) & $10.000-100.000$ \\
Air garam (brines) & $>100.000$ \\
\hline
\end{tabular}

Sumber: Hasil Pegolahan Data, 2021

Hasil pengukuran di lapangan menunjukkan bahwa nilai TDS daerah penelitian berkisar antara $104 \mathrm{mg} \mathrm{l}^{-1}$ hingga $227 \mathrm{mg} \mathrm{l}^{-1}$. Apabila mengacu pada klasifikasi Davis dan de Weist (1966), maka jenis air tanah pada daerah penelitian termasuk pada kategori fresh water yang memiliki kisaran nilai TDS $0-1.000 \mathrm{mg} \mathrm{1}^{-1}$ (Tabel 7).

Tabel 7. Klasifikasi jenis air tanah wilayah penelitian (Davis dan de Weist, 1966),

\begin{tabular}{ccccc}
\hline Kode & Jenis Sumur & Jenis kuifer & TDS mg/L) & $\begin{array}{c}\text { Jenis Air Tanah } \\
\text { (Davis dan de Weist, 1966) }\end{array}$ \\
\hline P1 & Sumur Bor & Tertekan & 141 & Fresh water \\
P2 & Sumur Bor & Tertekan & 165 & Fresh water \\
P3 & Sumur Bor & Tertekan & 227 & Fresh water \\
P4 & Sumur Bor & Tertekan & 109 & Fresh water \\
P5 & Sumur Bor & Tertekan & 172 & Fresh water \\
P6 & Sumur Bor & Tertekan & 136 & Fresh water \\
P7 & Sumur Bor & Tertekan & 212 & Fresh water \\
P8 & Sumur Bor & Tertekan & 139 & Fresh water \\
P9 & Sumur Bor & Tertekan & 104 & Fresh water \\
\hline
\end{tabular}

Sumber: Hasil Pegolahan Data, 2021

\section{b. Nilai Daya Hantar Listrik (DHL)}

Untuk menghantarkan arus listrik, ion-ion bergerak dalam larutan memindahkan muatan listriknya yang bergantung pada ukuran dan interaksi antar ion dalam larutan. Nilai DHL untuk berbagai jenis air (Mandel, 1981) adalah sebagai berikut (Tabel 8).

Tabel 8. Nilai Daya Hantar Berbagai Jenis Air (Mandel, 1981)

\begin{tabular}{lc}
\hline Jenis Air & Nilai DHL $\left(\boldsymbol{\mu S} \mathbf{~ c m}^{-1}\right)$ \\
\hline Air destilasi (aquades) & $0,5-5,0$ \\
Air hujan & $5,0-30$ \\
Air tanah segar & $30-2.000$ \\
\hline
\end{tabular}




\begin{tabular}{lc}
\hline Jenis Air & Nilai DHL $\left(\boldsymbol{\mu S ~ \mathbf { ~ c m } ^ { - 1 } )}\right.$ \\
\hline Air laut & $45.000-55.000$ \\
Air garam (brine) & $>90.000$ \\
\hline
\end{tabular}

Sumber: Hasil Pengolahan Data

Daya Hantar Listrik (DHL) atau konduktivitas merupakan gambaran numerik dari kemampuan air untuk meneruskan aliran listrik. Semakin banyak garam terlarut yang dapat terionisasi, maka semakin tinggi pula nilai DHLnya. DHL erat kaitannya dengan nilai salinitas suatu perairan. Semakin tinggi nilai salinitas suatu perairan makan semakin tinggi pula nilai DHL-nya.

Berdasarkan hasil pengukuran di lapangan, air tanah pada akuifer tertekan di daerah penelitian memiliki nilai DHL berkisar antara $773 \mu \mathrm{S} \mathrm{cm}^{-1}$ hingga $1.402 \mu \mathrm{S} \mathrm{cm}^{-1}$ (Tabel 5.6). Apabila mengacu pada klasifikasi Mandel (1981), maka jenis air pada daerah penelitian adalah air tanah segar dengan kisaran nilai DHL antara $30-2.000 \mu \mathrm{S} \mathrm{cm}^{-1}$ (Tabel 9). Nilai DHL air tanah pada akuifer tertekan di daerah penelitian belum memnunjukkan adanya pengaruh intrusi air laut.

Tabel 9. Klasifikasi Jenis Air Pada Daerah Penelitian Berdasarkan Mandel (1981)

\begin{tabular}{ccccc}
\hline Kode & Jenis Sumur & Jenis Akuifer & DHL $(\mu \mathrm{S} / \mathrm{CM})$ & $\begin{array}{l}\text { Jenis Air } \\
(\text { Mandel, 1981) }\end{array}$ \\
\hline P1 & Sumur Bor & Tertekan & 945 & Air tanah segar \\
P2 & Sumur Bor & Tertekan & 880 & Air tanah segar \\
P3 & Sumur Bor & Tertekan & 890 & Air tanah segar \\
P4 & Sumur Bor & Tertekan & 834 & Air tanah segar \\
P5 & Sumur Bor & Tertekan & 1138 & Air tanah segar \\
P6 & Sumur Bor & Tertekan & 866 & Air tanah segar \\
P7 & Sumur Bor & Tertekan & 1402 & Air tanah segar \\
P8 & Sumur Bor & Tertekan & 773 & Air tanah segar \\
9 & Sumur Bor & Tertekan & 786 & Air tanah segar \\
\hline
\end{tabular}

Sumber: Hasil Pengolahan Data, 2021

\section{Upaya Pengelolaan dan Konservasi Air Tanah}

Meskipun jenis air tanah pada semua sampel penelitian termasuk dalam jenis air tanah segar atau fresh water, akan tetapi nilai DHL atau tingkat salinitas pada dua sumur bor (P5 dan P7) berada pada tingkat kerusakan dalam kategori rawan. Peningkatan nilai salinitas air tanah pada sumur P5 dan P7 dibandingkan dengan sumur bor lainnya ditunjukkan oleh nilai DHL sebesar $1138 \mu \mathrm{S} \mathrm{cm}^{-1}$ dan $1402 \mu \mathrm{S} \mathrm{cm}^{-1}$. Meningkatnya nilai salinitas atau DHL air tanah dapat disebabkan oleh eksploitasi air tanah secara berlebihan. Ketika melakukan pemompaan air tanah pada akuifer yang berhubungan dengan hidraulik air laut, maka hal ini dapat menyebabkan terjadinya aliran air asin dari laut menuju akuifer sumur tersebut (Freeze and Cherry, 1979).

Beberapa upaya untuk menjaga keberadaan dan mencegah terjadinya kerusakan kondisi dan lingkungan air tanah antara lain (PP Air Tanah No. 34 Tahun 2008) : (a) melakukan perlindungan dan pelestarian air tanah; (b) melakukan pengawetan air tanahl; dan (c) melakukan pengelolaan kualitas dan pengendalian pencemaran air tanah. Pelestarian air tanah merupakan usaha menjaga kelestarian kondisi dan lingkungan serta fungsi air tanah agar tidak mengalami perubahan. Pengawetan air tanah dilakukan untuk menjaga kesinambungan ketersediaan air tanah dalam kuantitas dan kualitas yang memadai guna memenuhi kebutuhan hidup. Kodoatie \& Sjarief (2002) menyatakan bahwa pengelolaan sumber daya air termasuk sumber mata air ini meliputi beberapa aspek antara lain: pemanfaatan, pelestarian dan pengendalian. Mindawati, Kosasih, \& Heryati (2006) menyatakan evaluasi dampak dari upaya alternatif terhadap kuantitas air, dan rekomendasi upaya yang akan menjadi dasar dan pedoman dalam pengelolaan wilayah sungai di masa mendatang.

a. Perlindungan dan pelestarian air tanah dapat dilakukan melalui :

1. Menjaga daya dukung dan fungsi daerah imbuhan air tanah, dengan cara : 
- Pemeliharaan fungsi resapan air dan daerah tangkapan air

- Pengendalian pemanfaatan air yang diwijudkan dengan larangan pengeboran, penggalian atau kegiatan lain dalam radius 200 meter dari lokasi pemunculan mata air

- Pengisian air pada sumber air

2. Menjaga daya dukung akuifer, dengan cara :

- Pengaturan sarana dan prasarana sanitasi

- Perlindungan sumber air dalam kaitannya dengan kegiatan pembangunan dan pemanfaatan lahan pada sumber air

- Pengendalian pengolahan tanah di daerah hulu

- Pengaturan daerah sempadan sumber air

3. Memulihkan kondisi dan lingkungan air tanah pada zona kritis dan zona rusak

- Rehabilitasi hutan dan lahan dan/atau

- Pelestarian hutan lindung, kawasan suaka alam dan kawasan pelestarian alam, yang diwujudkan dalam pembatasan penggunaan air tanah hanya untuk pemenuhan kebutuhan pokok sehari-hari

b. Pengawetan air tanah dilaksanakan dengan cara :

1. Mengendalikan pengambilan dan pemanfaatan air tanah

Pengendalian pengambilan dan pemanfaatan air tanah dilakukan untuk menjaga keseimbangan antara ketersediaan dan pemanfaatan air tanah sehingga tidak merusak kondisi dan lingkungan air tanah, dapat dilakukan dengan cara :

- Penerapan perizinan air tanah

- Pengaturan debit pengambilan air tanah

- Pengaturan pelaksanaan dewatering

- Pengaturan debit penurapan mata air

- Pengaturan pemanfaatan air tanah

- Penetapan tarif progresif yang ketat sesuai dengan kondisi air tanah

2. Menghemat pemanfaatan air tanah

Upaya penghematan pemanfaatan air tanah dilakukan untuk efisiensi dan efektivitas pemanfaatan air tanah, dapat dilakukan dengan cara :

- Daur ulang

- Pemanfaatan diprioritaskan untuk memenuhi kebutuhan pokok air minum dan tumah tangga

- Pengambilan sesuai kebutuhan

- Pemanfaatan air tanah sebagai alternatif terakhir selama masih tersedia air yang lain
- Gerakan hemat air

3. Meningkatkan kapasitas resapan air

- Membuat imbuhan air tanah buatan, yaitu membuat sumur-sumur imbuhan, pelestarian hutan, danau, situ, bendungan, jaringan irigasi, pembuatan embung di sepanjang sungai, penataan ladang/kebun dan kavling perumahan yang dilengkapi sumur pantau

- Merehabilitasi daerah imbuhan air tanah, dengan melakukan reboisasi hutan jika kepadatan pohon kirang atau mengalami degradasi, penataan ladang/kebun pada lahan yang bertopografi miring $( \pm 6 \%)$ dengan metoda terrassering

4. Mendorong penggunaan air yang saling menunjang (conjuctive use) antara air tanah dengan air selain air tanah

c. Pengelolaan kualitas dan pengendalian pencemaran air tanah

Ada tiga kegiatan utama dalam melakukan pengelolaan kualitas dan pengendalian pencemaran air tanah, antara lain :

1. Mencegah pencemaran air tanah

2. Menanggulangi pencemaran air tana

3. Memulihkan kualitas air tanah yang telah tercemar

\section{KESIMPULAN}

Secara umum daerah imbuhan air tanah di daerah penelitian tersusun oleh batuan sedimen yang berumur pra-Trias hingga Resen. Sebaran daerah imbuhan tersebut meliputi $43 \%$ dari luas wilayah daratan Kota Baubau atau seluas $96 \mathrm{~km}^{2}$. Morfologi daerah imbuhan merupakan wilayah perbukitan rendah, perbukitan hingga perbukutan tinggi dengan ketinggian 100 hingga 700 meter di atas permukaan laut. Berdasarkan parameter nilai TSD dan DHL, tingkat kerusakan air tanah pada daerah penelitian adalah terdapat 7 sumur bor masih dalam kategori aman, sedangkan 2 sumur bor lainnya masuk dalam kategori rawan. Adapun jenis air tanah pada daerah penelitian termasuk pada kategori fresh water yang memiliki kisaran nilai TDS $0-1.000 \mathrm{mg} 1^{-1}$. Berdasarkan hasil pengukuran di lapangan, air tanah pada akuifer tertekan di daerah penelitian belum memnunjukkan adanya pengaruh intrusi air laut dengan nilai DHL berkisar antara $773 \mu \mathrm{S} \mathrm{cm} \mathrm{cm}^{-1}$ hingga $1.402 \mu \mathrm{S} \mathrm{cm}{ }^{-1}$ dan dikategorikan sebagai air ganah segar dimana 
nilai DHL masih berada dalam kisaran $30-2.000$ $\mu \mathrm{S} \mathrm{cm}^{-1}$.

Ucapan Terima Kasih: Penelitian ini tidak dapat terselesaikan jika tidak ada bantuan dari berbagai pihak, khusunya dari PDAM Kota Baubau, masyarakat yang telah memberikan informasi dan yang telah memberikan bantuan secara moril mauun materi.

\section{DAFTAR PUSTAKA}

Bear, J., 1979. Hidroulics of Grpundwaterof. McGraw-Hill Book Company, New York

Davis S. N dan de Wiest. 1966. Hydrogeology. United States of America. Jelin Wilev \& Sons.

Delinom, R., 2007. Sumber Daya Air Di Wilayah Pesisir Dan Pulau-Pulau Kecil Di Indonesia. Jakarta. Lembaga Ilmu Pengetahuan Indonesia, Pusat Penelitian Geoteknologi, LIPI Press

Freeze R. A dan J. A. Cherry. 1979. Groundwater. Prentice - Hall, Inc., Englewood Cliffs, New Jresey.

Harimu, La, Haerduddin, Sulha, dan Saprin. 2019. Kualitas Air dan Sumber Mata Air Karaa dan Upaya Pelestariannya. Kainawa: Jurnal Pembangunan \& Budaya, 1(1) 59 - 72
Kodoatie, R. J., \& Sjarief, R. (2002). Pengelolaan Sumber Daya Air dalam Otonomi Daerah. Yogyakarta: Penerbit Andi.

Kodoatie, R. J., 2012. Tata Ruang Air Tanah. Yogyakarta: Penerbit ANDI.

Mindawati, N., Kosasih, A. S., \& Heryati, Y. (2006). Pengaruh Penanaman Beberapa Jenis Pohon Hutan Terhadap Kondisi Kesuburan Tanah Andosol. Jurnal Penelitian Hutan Tanaman, 3(3), 755-764.

Sikumbang, N., Sanyoto, P., Supandjono, R.J.B., Gafoer, S., 1995. Peta Geologi Lembar Buton, Sulawesi, skala 1:250.000. Pusat Penelitian dan Pengembangan Geologi, Bandung.

Supangat, A. B. (2008). Pengaruh Berbagai Penggunaan Lahan Terhadap Kualitas Air Sungai Di Kawasan Hutan Pinus Di Gombong, Kebumen, Jawa Tengah. Jurnal Penelitian Hutan Dan Konservasi Alam, 5(3), 267-276.

United Nations Educational, Scientific and Cultural Organization (UNESCO), 1984. Groundwater in Hard Rock. Published in 1984 by the United Nations Educational, Scientific and Cultural Organization, 7, place de Fontenoy, 75700 Paris.

Zuidam R. A. van., 1985. Aerial PhotoInterpretation in Terrain Analiysis and Geomorphologic Mapping. Smith Publisher, The Hague, ITC. 